\title{
Músicas, músicos e crítica musical francesa em Mário de Andrade
} LIGIA FONSECA FERREIRA I e LIGIA KIMORI II

\begin{abstract}
“A crítica é uma obra-de-arte, gente. A crítica é uma invenção sobre um determinado fenômeno artístico, da mesma forma que a obra-de-arte é uma invenção sobre um determinado fenômeno natural" (Mário de Andrade, “Começo da crítica”, Diário de Notícias. 5.3.1939)
\end{abstract}

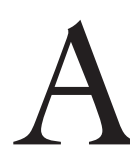

LEITURA das crônicas publicadas em Música, doce música (1963) traz temas e aspectos novos da relação de Mário de Andrade com a França, em geral por ele considerada de forma contrabalançada e nas antípodas do deslumbramento que caracteriza a postura da maior parte dos artistas e intelectuais brasileiros de sua geração. Em algumas dessas crônicas, o autor tece críticas à música francesa de Lully (1632-1687) a Ravel (1875-1937), recorre às explicações de historiadores e teóricos musicais franceses, além de discutir, questionar e rebater as opiniões de críticos musicais franceses sobre a música de seu próprio país e, especialmente, sobre a música brasileira. Foi nessa obra que selecionamos o corpus da análise apresentada neste artigo: trata-se de um total de seis artigos, escritos no período de 1930 a 1944 para diferentes jornais - Estado de S. Paulo, Diários Associados e Correio da Manhã.

Curiosamente, nosso levantamento bibliográfico sobre o tema revelou a existência de um número restrito de trabalhos sobre a presença da França e da cultura francesa na obra de Mário de Andrade. Dentre eles, destacaríamos, por seu caráter pioneiro, as Leituras em francês de Mário de Andrade, de Nites Therezinha Feres (1969), publicada pelo Instituto de Estudos Brasileiros em 1969. Em sua biblioteca particular, Mário possuía inúmeros exemplares de obras em língua francesa, fator importante para se compreender as raízes de algumas de suas ideias. A autora mostra, portanto, como se dá a formação de Mário de Andrade à luz de suas leituras francesas, especialmente as relativas ao campo da psicologia. Conclui, no entanto, que o recorte escolhido apresentava-se, apenas, como a ponta de um iceberg:

As obras de psicologia não esgotam o tema das leituras em francês de Mário de Andrade. Elas abrangem obras que, pela sua natureza, se incluem nos mais diversos campos do conhecimento humano. [...] Portanto, o prestígio da cultura francesa está apenas exemplificado pelos livros selecionados até agora, os quais estão longe de esgotar a totalidade. (Feres, 1969, p.80) 
Em Mariodeandradiando, Telê Ancona Lopez (1996, p.3) ressalta as marcas francesas e/ou francófonas presentes em Há uma gota de sangue em cada poema, de 1917, obra de estreia do jovem poeta, que se declarava influenciado pela "França que o educara" e pela "Bélgica que admirava", em particular através da poesia de Émile Verhaeren.

Num espaço de quase trinta anos, embora proliferassem trabalhos sobre o escritor, não se registraram estudos voltados para a relação de Mário com o universo francês ou de língua francesa. Em 2004, A França nos contos de Mário de Andrade, dissertação de Valter César Pinheiro (2004), propôs-se a analisar a construção de um "ponto de vista francês" na contística do autor modernista, bem como apontar outras influências hauridas em fontes francesas.

No capítulo "Galofilia e galofobia na cultura brasileira", Leyla Perrone-Moysés (2007, p.50-80) evoca as "relações tensas" de Mário de Andrade com a cultura francesa, identificáveis em vários escritos. Mergulhado na reflexão sobre as coisas que conformariam a "identidade brasileira", o escritor símbolo modernista conclamava seus contemporâneos a abandonarem seus gostos e ares "afrancesados". Dedicando-lhe um lugar privilegiado em sua análise, Perrone-Moysés alerta, no entanto, para o fato de Mário de Andrade nunca ter-se furtado a demonstrar a "complexidade" das relações do Brasil, como também da América Latina, com a França, o que não o torna nem "galófilo" nem "galófobo", mas dono de uma visão "realista e lúcida" (ibidem, p.73).

A ausência de estudos particularmente dedicados às referências francesas nas críticas do musicólogo formado em piano e canto pelo Conservatório Dramático e Musical de São Paulo, do qual também se tornaria professor de História da Música e Estética, instigou-nos o tema aqui examinado. Procuramos analisar em Música, doce música como se constrói a visão de Mário de Andrade sobre a música francesa em comparação com a de outros países europeus e com a do Brasil, bem como identificar as eventuais influências recebidas de historiadores, teóricos ou críticos musicais franceses. Interessou-nos, pois, investigar o lugar ocupado pelas referências francesas nesse universo e verificar se a postura de Mário de Andrade permaneceria, também nesse campo, ditada por seu obstinado desejo de reequilibrar as relações com o Outro-europeu, na medida em que ele se propõe a julgar daqui a produção de lá (no caso, da França), quando não a corrigir visões distorcidas de musicólogos franceses sobre a expressão musical brasileira. Para tanto, evocaremos alguns elementos da cultura francesa presente na formação do autor de Música, doce música; em seguida, indicaremos algumas características de sua prosa jornalística e o lugar das crônicas musicais nesse conjunto, antes de dedicar-lhes uma análise de conteúdo mais detalhada.

\section{As referências francesas, o universo musical e o jornalismo crítico A influência da França}

O paulistano Mário Raul de Moraes Andrade, nascido em 9 de outubro de 1893, manifestou seu talento em inúmeras áreas. Em 1910, frequentou a Facul- 
dade de Filosofia e Letras da Faculdade de São Paulo, ligada à Universidade de Louvain (Bélgica); a sólida formação resultou dos cursos ali ministrados por professores belgas e franceses, além das leituras e de toda a influência provinda da França na época. O próprio Mário de Andrade reconheceria mais tarde o reflexo desse processo em sua obra quando mostra "sua identificação profunda 'com a França que o educara”" e "com a Bélgica que admirava” (Lopez, 1996, p.3).

Em sua biblioteca particular, constituída por mais de dezessete mil volumes, Mário de Andrade possuía livros sobre os mais variados assuntos como "literatura, música, folclore, teatro, antropologia, artes plásticas, etnografia, educação, ortografia, medicina, construções navais, provérbios, cantos de pássaros" (Paulino, 1990). Além disso, cumpre ressaltar que várias dessas obras estão escritas em língua francesa. Segundo Nites Feres (1969, p.9), "o número de textos em língua francesa, existentes na biblioteca do escritor, mostrou que ela teve relevância como mediadora de ideias e teorias".

É importante destacar que ele fazia tanto apontamentos em textos de língua francesa como mencionava livros, autores e trechos franceses nas margens de obras brasileiras. Tal fato comprova a dedicação com que o autor se lançava em suas análises, bem como a bagagem de referências lhe permitiam estabelecer ligações entre as mais diversas leituras.

A partir de 1920, Mário de Andrade torna-se assinante e grande leitor de revistas europeias, tais como Nouvelle Revue Française, Europe, The London Mercury, Der Querchnitt, e é apresentado à crítica francesa. Vale ressaltar que o profundo conhecimento da cultura francesa foi amealhado através de revistas e livros, além dos cartões-postais que, enviados por amigos, traziam imagens e comentários: o autor jamais foi à França, a exemplo de muitos escritores brasileiros da época. Numa de suas crônicas, ele próprio faz uma reflexão a respeito do que reconhece ser uma lacuna em sua trajetória intelectual: "é trágico isso do artista que nunca viu Paris" (Andrade, 1940). Para ele, se a tivesse realizado, tal viagem seria mais uma conquista merecida pelos anos de inspiração e estudo, do que uma real possibilidade de aprimorar os conhecimentos já bastante fartos sobre a vida intelectual e os tesouros culturais parisienses.

\section{A formação musical}

Desde muito jovem preocupado com sua formação, aos 16 anos Mário de Andrade já frequentava concertos e conferências. É nessa época que começa a estudar piano em casa. Dois anos mais tarde, entra para o Conservatório ambicionando tornar-se concertista, motivo pelo qual se envolve completamente com a música e passa a ser monitor do curso até ser contratado como professor substituto de História da Música.

Em 1913, Mário sofre um profundo abalo em virtude do falecimento de seu irmão mais novo e mergulha em uma crise emocional. Afastado de tudo por um longo período, retorna como um poeta assumido, mas desiste da carreira de concertista, visto que suas mãos tornaram-se demasiado trêmulas. Passa, en- 
tão, a ministrar efetivamente as disciplinas de História da Música e Estética no mesmo Conservatório Dramático e Musical de São Paulo, do qual se tornará professor catedrático em 1922.

Mário de Andrade foi pioneiro como musicólogo. Ao longo de sua vida, escreveu sobre música erudita em geral, colonial brasileira, religiosa e profana; estudava as bibliografias musicais e tinha uma apurada sensibilidade. Segundo Henrique Alves (1973), a história da música no Brasil tem um marco antes e depois de Mário de Andrade, por ter ele diluído os tabus e formalismos europeus obsolescentes na época. Além disso, a música brasileira ainda não havia passado por uma devida estruturação e a Mário coube a tarefa de examiná-la e historiá-la em várias obras, como se verá adiante.

De 1935 a 1938, período em que dirigiu o Departamento de Cultura da Cidade de São Paulo, promoveu concursos musicais e criou casas de cultura e parques infantis onde eram cantadas músicas populares e realizadas danças dramáticas. Instituiu também o Primeiro Congresso da Língua Nacional Cantada em 1937, em que mestres estabeleceriam normas de canto em nossa língua. Ainda nessa área, desenvolveu uma Biblioteca Pública, uma Discoteca Pública e um laboratório de fonética, que deixou sob os cuidados de sua aluna Oneyda Alvarenga. Suas iniciativas incluem ainda a abertura do Teatro Municipal aos trabalhadores, a fundação da Escola Paulista de Música e a criação da Orquestra Sinfônica Municipal. ${ }^{1}$

Além de utilizar-se de sua vasta biblioteca, Mário possuía outras fontes de pesquisa musical, como discos de grandes compositores, coleção de partituras impressas e os programas dos já mencionados concertos a que assistia. $\mathrm{O}$ que mais surpreende na relação de Mário de Andrade com o universo musical é, conforme assinala Flávia Toni (1990), “a familiaridade com que o professor cita nomes e obras da produção musical do Ocidente, compositores de todas as épocas, contemporâneos dele, inclusive"; estava ele sempre inteirado dos fatos musicais, tratados nos principais jornais e periódicos da cidade e do país.

Ao lado das artes plásticas e do folclore, a música constituiu um foco de interesse duradouro para Mário de Andrade, tendo sido objeto de vários estudos, parte deles, inclusive, publicados postumamente: Ensaio sobre a Música Brasileira (1928), Compêndio de História da Música (1929) (reescrito como Pequena história da música em 1942), Modinhas imperiais (1930), Ensaios Sobre a Música Brasileira e A Música e a Canção Populares no Brasil (1962), Aspectos da música brasileira (1965), Música de feitiçaria no Brasil (1983), Dicionário Musical Brasileiro (1989).

Nesse conjunto, é importante observar como dali sobressai a forte relação de Mário de Andrade com dois temas recorrentes em sua produção: as referências à França e o gosto pela música, que desde muito cedo permeiam a trajetória do crítico e musicólogo que colabora em mais de dez jornais, escrevendo sobre um leque de temas os mais variados. 


\section{A produção jornalistica}

O primeiro artigo de Mário de Andrade na imprensa é justamente uma crônica musical, "No Conservatório Dramático e Musical: Sociedade de Concertos Clássicos" publicada no Jornal do Comércio em 11 de setembro de 1915. De 1921 a 1923, escreve também para A Gazeta e colabora no Correio Paulistano. Mas é de agosto de 1927 a setembro de 1932 que Mário de Andrade se estabelece como crítico de arte graças à sua colaboração no Diário Nacional. Nesse periódico, o autor modernista publica cerca de setecentos artigos, sendo mais de quatrocentos sobre música (Castagna, 1993, p.XV).

Em maio de 1933, ele passa a escrever igualmente para outro jornal, o Diário de S. Paulo e, em dois anos, escreve aproximadamente 160 artigos onde "encontramos os mais curiosos aspectos da crônica musical paulistana do início da década de 30" (ibidem, p.XVIII). Antes de deixar esse jornal, Mário lista seus feitos mais importantes, quase todos pioneiros, segundo ele próprio, em carta a Sousa da Silveira em 15 de fevereiro de 1935:

Resolvi trabalhar a "matéria” brasileira, especificá-la, determiná-la o quanto em mim e na complexidade dela. $\mathrm{O}$ caso linguístico não é senão um dos muitos corolários dessa realização de mim. Digo "de mim" e não do Brasil, porque sabia muito conscientemente, desde o princípio, que se tratava de dar minha contribuição pessoal, e não, com o meu serzinho minúsculo realizar o sentido e a imagem do Brasil. Não havia folclore musical brasileiro. Fiz folclore musical brasileiro. Não havia crítica de arte em S. Paulo, e a pouca brasileira existente era mais que péssima. Fiz crítica de arte. Não havia um tratado de poética, moderno, adaptável ao tempo. Fiz um. Não havia História da Música em nossa língua. As existentes eram simplesmente porcas. Fiz uma, bem melhor que as outras. Etc. (Fernandes, 1968, p.150, apud Castagna, 1993, p.XVIII)

A respeito disso, para a publicação de Música, doce música, Mário de Andrade afirma ter escolhido as críticas "dignas de permanência em livro", pois percebia a carência que seus alunos de música tinham para acessar maiores informações sobre o assunto. No entanto, o escritor frisa que, originalmente, tais artigos não foram feitos para permanecer, salientando seu caráter efềmero, como tudo o que se publica em jornais. Ainda assim, no intuito de satisfazer a curiosidade de seus discípulos, o professor se dispôs a reunir seus escritos com uma finalidade pedagógica.

\section{- A crítica como gênero textual}

Através da crítica, o público é despertado a compreender a emoção de artistas e autores, pois cabe ao crítico reformular a sensibilidade por meio de uma parcialidade, a fim de tanger elementos universais. A função do crítico é, portanto, completar o sentido mais extenso da obra para poder interpretá-la e imbuí-la de significado, tornando-a mais palatável para o leitor. Porém, nenhuma escrita é absolutamente objetiva ou neutra e o crítico sempre coloca seu parecer de alguma forma. 
Por esse motivo, desde o século XIX, a crítica foi, aos poucos, adquirindo um papel tutelar na sociedade. Desse modo, acabou por inserir ou afastar escritores, obras, peças e músicas, já que os críticos têm a capacidade - ou, melhor dizendo, ganharam o poder - de classificar as artes ou de sequer admitir uma posição para estas dentro da sociedade. Por vezes, a crítica tende a suplantar a própria obra, quando assume um tom de verdade e soberania. Além disso, observa-se uma evolução progressiva do gênero, calcada em conceitos e terminologia mais próximos do registro literário do que jornalístico, o que tende a aproximá-la da literatura, inclusive do ponto de vista estilístico.

Essa expressão subjetiva do crítico fica bastante explícita nos artigos aqui analisados, porém há uma característica que faz que a crítica de Mário de Andrade tenha um quê diferente. Ao comentar eventos culturais ou dar suas impressões sobre inúmeras obras, o autor se vale de artifícios próprios das crônicas e não forçosamente das "críticas", mesclando assim ambos os gêneros: ele começa constantemente relatando algum fato importante ou elementos de seu cotidiano que lhe servem de argumento ou ponto de partida para a crítica que se seguirá.

A utilização desse recurso resulta numa aproximação de Mário de Andrade com os leitores, na medida em que, ao envolvê-los, compartilhando com eles fatos prosaicos, prepara o terreno para a persuasão, dá embasamento e legitimidade às suas apreciações críticas. Essas talvez visassem, indiretamente, preencher algumas lacunas detectadas pelo "professor" Mário, cujo empenho na (in) formação cultural e artística do público jamais esmoreceu. Vale ressaltar que a atividade crítica do escritor paulistano não se resumiu a tecer avaliações de obras ou fatos de literatura, abrangendo as artes plásticas, a arquitetura, o folclore e, naturalmente, a música, um de seus campos de predileção.

\section{- Ethos do autor e imagem do público leitor}

Após examinar os textos selecionados - "O Bolero de Ravel" (1930), "Laforgue e Satie"(1939), "Teutos, mas músicos" (1939), "A modinha e Lalo" (1941), "Romain Rolland, músico" (1944), “Oferta Musical” (s.d.) -, notam-se características específicas em cada artigo e nuances na postura enunciativa.

Para reconhecer os elementos embutidos no discurso de Mário de Andrade, é necessário reconhecer a cenografia discursiva por ele utilizada: a imagem que passa de si mesmo, a imagem que acredita terem dele os seus leitores, e, por fim, a maneira como vê esses últimos. O ethos, que constrói a imagem de si no fio da enunciação, está implícito nos discursos, sejam esses orais, sejam escritos. Essa imagem deve apresentar-se de maneira estimulante para que haja uma assimilação, bem como um desejo de incorporação dessa pelos leitores, como explica Maingueneau (2001, p.100): "Para exercer um poder de captação, o ethos deve estar afinado com a conjuntura ideológica". O leitor, portanto, deverá sentir-se persuadido pelo discurso embutido na crítica, reconhecendo ali o argumento daquele que se enuncia. 
O primeiro fator inegável é que a escrita de Mário de Andrade exige muito dos leitores, seja porque supõe seu conhecimento prévio, seja por introduzir novos saberes, como se depreende das constantes menções a figuras eruditas e/ ou dele contemporâneas: nomes como Cézanne, Da Vinci, Bach, Beethoven, Debussy, Liszt, Mozart, Ravel, Wagner, Balzac, Baudelaire, Goethe, Mallarmé, Bastide, Stravinski, além dos nacionais Camargo Guarnieri, Henrique Oswald, Villa-Lobos, Cecília Meirelles, Bandeira, Drummond, Guiomar Novais, Oneyda Alvarenga, são citados inúmeras vezes figurando como pontos de referência nas apreciações ou comparações artísticas. Além disso, o autor supõe um leitor fluente em francês, característica dos homens cultos de seu tempo, pois faz citações no original certo de que não causará empecilhos à compreensão, mesmo em períodos onde se engatam frases nas duas línguas:

"Si Baudelaire avait mis psychologiquement son coeur à nu, Verlaine l'a mis musicalement à nu. Aucune parole n'est plus que la sienne proche de ce qui ne peut être dit" que é exatamente a conceituação romântica de música".

"Oferta musical" (Andrade, 1963, p.383)

Com julgamentos brandos ou incisivos, Mário se coloca, exprime suas emoções a todo momento. Isso é perceptível no levantamento das exclamações, bem como dos verbos de julgamento e opinião na primeira pessoa:

"Que prodígio de virtuosidade técnica é a orquestra do Bolero! É fantástico. Jamais a orquestra impressionista, mesmo com Debussy (tão superior, no entanto!...), soou com a sabedoria de equilíbrio".

"O Bolero de Ravel" (ibidem, p.260)

Tendo em vista essa forte característica em seus escritos, jamais deixa dúvidas quanto ao seu apreço ou restrições quanto ao tema abordado. Além disso, através de inúmeras perguntas retóricas dirigidas ao leitor, Mário assume um tom professoral, quase pedagógico, próprio de quem deseja, além de dialogar, instruir:

"Ravel presenciou e auxiliou todo o experimentalismo sinfônico do nosso tempo. Soube compreendê-lo? Me parece que absolutamente não".

"O Bolero de Ravel" (ibidem, p.259)

Percebe-se em todas as críticas sua tentativa constante de mostrar-se um intelectual preocupado com a cultura de seu tempo. Desejando criar um discurso brasileiro sobre a música, faz inúmeras tentativas de aclimatar a temática sob todos os aspectos, não se limitando ao campo cultural brasileiro, tanto em exemplos quanto em comentários.

\section{- Impressões formais}

Outro traço marcante nas críticas de Mário é a explicitação de sua metodologia de pesquisa, às vezes de forma detalhada e em outras apenas evocando percursos, ou percalços, como no exemplo a seguir:

"E eis-me na maior das dificuldades. A principio gritei, clamei instintivamente "Não!". Depois, com bastante má vontade, perguntei "Sim"? Pen- 
sando melhor em seguida, continuei dizendo "não", porém, recordando que as árvores genealógicas tem numerosíssimos galhos que tanto produzem limão como lima, fiquei, como na cantiga de Nepomuceno, "meio sim, meio não". Vamos estudar com alguma paciência este caso.”

"Laforgue e Satie" (ibidem, p.298)

O recurso empregado proporciona ao leitor um contato direto com os procedimentos adotados para construir a argumentação de um autor solidário, que não se incomoda em revelar tanto sua forma de desenvolver o raciocínio como de lidar com suas indecisões metodológicas.

Assim como nos seus contos ou romances, também nas análises críticas de Mário de Andrade encontram-se traços de seu humor peculiar e com ligeiro tom de sátira, reflexos de um efeito produzido por uma informalidade instaurada pelo jeito "à-vontade" com que estabelece um "bate-papo" com o leitor. Nos artigos sobre música encontram-se, pois, muitos traços de oralidade, tais como as repetições:

"Mas em que nos adianta ele? Em nada. Em nada adianta aos esforços dos novos. E não adianta nada como música. Não adianta nada aos esforços dos novos".

"O Bolero de Ravel” (ibidem, p.260)

ou mesmo as múltiplas negações que quase ferem a sintaxe vernacular:

“A filosofia germânica que nunca jamais ninguém não entendeu direito."

"não acreditem muito não"

"Laforgue e Satie” (ibidem, p.298-9)

Há ainda a utilização do recurso de parataxe, que consiste na ligação de constituintes linguísticos através de coordenação, como no caso seguinte:

“E por todas essas razões, ele não adianta nada ao período em que aparece.

E ainda falei que não adianta nada como música. É fato.”

"O Bolero de Ravel” (ibidem, p.260)

Assim como em outros textos, nas crônicas musicais encontram-se o uso de palavras coloquiais, arcaísmos e expressões populares, muitas delas oriundas da "língua brasileira": "na lata", "balela", "macacos me mordam", "inda", “pra”, “ora”, “Deus me perdoe”, “às moscas”, “a valer”, “duma”, “um bocado", entre outros. Além de uma pontuação que denota a linguagem falada, com pausas longas produzidas pelo recurso às reticências ("Essa 'musicalidade' de Paul Verlaine... Sim, existirá essa musicalidade nos versos dele” [ibidem, p.382]) ou ainda exteriorização de sentimentos concomitantes ao discurso, como se depreende das frases exclamativas ("Como é bom recordar, na desgraça, os tempos felizes!...” [ibidem, p.316]). Notam-se, assim, alguns dos procedimentos estilísticos típicos do modernismo, e de Mário em particular, em sua tentativa de filtrar a forma de expressão dos brasileiros, o que vai além de um mero retrato ou de simplesmente espelhar o "falar do povo". As marcas orais sem dúvida 
aproximam o enunciador de seu leitor, presentificando-o, como se fosse antes um ouvinte, aliás convidado a participar das discussões através dos questionamentos formulados pelo cronista.

Ao desenvolver suas ideias, Mário de Andrade (1993a, p.XIII) não se detém em modelos preconcebidos de análise. Desse modo, tem-se "a negação de rótulos absolutos", alcançada pela ausência de critérios rígidos de observação. As primeiras críticas do recorte selecionado (1930-1944) possuem um tom mais sarcástico e agressivo. Com o passar do tempo, percebe-se a atenuação da irreverência e uma consequente ponderação por parte do crítico. O número de comparações aumenta consideravelmente e os artigos musicais assumem um tom mais literário do que jornalístico; disso resulta uma escrita reflexiva, com análises mais equilibradas e profundas.

\section{Crônicas musicais analisadas}

\section{"O Bolevo de Ravel” (1930)}

Mário de Andrade faz uma análise do oitavo concerto da temporada Villa-Lobos. O Bolero de Ravel ganha destaque na apreciação quanto aos aspectos estéticos, culturais e de criação. Segundo o autor paulistano, Ravel estaria deslocado de seu tempo ("despudor de luxo setecentista") e teria como alvo um público fácil, visto que o Bolero impressiona pela sonoridade crescente, sendo porém vazio de sentido.

O Bolero, estreado na Ópera de Paris em 11 de novembro de 1928, é a obra mais famosa de Ravel, composta para a coreografia de um balé. Em sua crônica, Mário faz afirmações incisivas, quando não depreciativas sobre o valor estético da obra do músico francês: "não adianta nada como música", "o bolero é um desperdício desumano e diletante", "musicalmente fácil e esteticamente complicadíssima", "esmolinha econômica e falsamente luxuosa", além de outras inúmeras expressões que evidenciam o ponto de vista insistentemente desaprovador do Bolero.

Trata-se de um artigo curto e extremamente direto, o menor dentro do conjunto por nós analisado. O musicólogo paulista critica enfaticamente as sonoridades presentes no Bolero, sem importar-se com a reputação internacional de Ravel no cenário musical da época. As críticas ferozes de Mário de Andrade derrotam qualquer consenso permitindo ao sentir-se mais à vontade para tecer comentários e dar sua real opinião a respeito do consagrado Bolero.

Cumpre ressaltar que, nesse primeiro momento, Mário se atém ao assunto principal do artigo, sem grandes digressões ou explicitação de seus métodos de reflexão. São poucas as comparações feitas por ele: há uma rápida menção a Debussy, por Mário considerado superior aos italianos Mascagni, Respighi, Paganini, além de Liszt e Strauss, estes últimos colocados no mesmo plano que Ravel. Mário de Andrade exalta claramente os brasileiros Guiomar Novais e Villa-Lobos. Desse modo, embora a comparação se faça predominantemente com europeus, os artistas nacionais é que recebem os maiores elogios. 
O tema central do artigo gira em torno da produção musical francesa da época, sobre a qual discorre o cronista com uma propriedade e segurança que atestam seu conhecimento atualizado e domínio do assunto.

\section{"Laforgue e Satie" (9.7.1939)}

Mário de Andrade sustenta que é possível fazer comparações entre diferentes artistas de uma mesma arte, "porém, entre artes diferentes, mesmo certos elementos gerais identificáveis entre si, não identificam personalidades" (Andrade, 1963, p.299). Tornar-se-ia, pois, difícil a tarefa, solicitada por Sérgio Milliet, de buscar aproximações entre o poeta Laforgue (1860-1887) e o compositor Satie (1866-1925). Embora franceses, pareciam delinear-se mais diferenças do que semelhanças. Para isso, o escritor paulistano se vale de uma descrição metódica de seu próprio processo de criação, permitindo ao leitor acompanhar tanto a linha de raciocínio quanto sua argumentação. Assim construído, o artigo ganha um tom mais ponderado, visto que Mário tece comparações com outros campos artísticos a fim de melhor ilustrar seu ponto de vista.

Em relação ao primeiro artigo musical analisado, há uma sensível diminuição das expressões de subjetividade, mesmo se ainda encontram-se frases como: "não acreditem muito não", "me repugna instintivamente", "meu Deus", entre outros. O tema central do artigo abrange vários aspectos da cultura francesa, razão pela qual comparecem nomes como Villon, Rictus, Racine, Victor Hugo (escritores), Poussin, Cézanne (pintores), Ravel, Debussy, Chopin ${ }^{2}$ (compositores). Faz-se ainda menção aos italianos Puccini, Rossini, Clementi, Da Vinci e Miguelangelo; a Wagner (Alemanha) e a Schumann (Saxônia) e aos brasileiros Lorenzo Fernandez, Villa-Lobos e Henrique Oswald. Novamente, encontramo-nos frente a modelos europeus, sobretudo franceses, e os artistas brasileiros pouco servem como parâmetro, à exceção de Henrique Oswald por sua espontaneidade e humor musical. Em contrapartida, Mário se derrama frente Racine mesmo se a pintura, na França, suplanta a poesia.

\section{"Teutos mas músicos" (31.12.1939)}

Em que pese o título provocativo, trata-se da crônica que mais explicita a relação algo conflitiva e doentia de Mário com a cultura francesa e de como, para curar-se dela, talvez fosse o caso de voltar os olhos para a pátria de grandes músicos, a Alemanha, de onde também provinham imigrantes estabelecidos em terras brasileiras. Lembremos que o mundo então assistia à ascensão nazista, responsável pela deflagração da Segunda Guerra havia pouco mais de três meses. Desde a introdução, compartilha com o leitor uma notícia recebida recentemente, ponto de partida para algumas paradoxais reflexões: "O Brasil está se esforçando, com muita razão, por abrasileirar as partes germanizadas do país, nas bandas do sul" (Andrade, 1963, p.314). Concordando, pois, com o que parecia ser um excesso e agora, talvez, uma ameaça, considerando-se o cenário mundial, o autor acha justo exigir-se a inclusão de uma parcela de música brasileira nos programas das "sociedades teuto-brasileiras do sul", exigência que talvez se de- 
vesse estender a sociedades das grandes cidades "[que] têm como grosso de seus sócios, estrangeiros, na sua maioria oriundos dos países germânicos" (ibidem, p.318). Com efeito, o censo do IBGE sobre a presença alemã no Brasil, no período de 1824 a 1969, indica que o país recebera o maior contingente de imigrantes nas décadas de 1920 e $1930 .^{3}$ O período no qual Mário escreve sua crônica é marcado por uma inflexão nas relações teuto-brasileiras. Segundo Boris Fausto (1994, p.380), entre 1934 e 1940 a participação da Alemanha no comércio exterior do Brasil aumentara sensivelmente, especialmente no setor de importações, transações vistas com apreço por todos quantos desejavam a modernização do país. O golpe de 1937 fora recebido com entusiasmo pelo regime nazista. No entanto, em 1938, sinalizando distância frente ao governo hitlerista, o Estado Novo acomete contra grupos nazistas presentes no sul do país, o embaixador alemão, declarado persona non grata, deixou o Brasil. Antes mesmo de o Brasil juntar-se aos aliados em janeiro de 1942, foi proibido o uso da língua alemã em escolas e em órgãos de imprensa do sul do país. Não deixa de soar curioso, para não dizer ousado, que Mário em sua crônica de 1939 aborde de forma palatável um assunto aparentemente neutro, ao comentar etapas de seu aprendizado da língua alemã e sua função culturalmente terapêutica:

Foi então que tive uma ideia bem malvada para me curar de minha francesite. Os ingleses são aliados, disse comigo, e já reparei que não me libertam dos franceses. Tenho que provocar uma guerra de morte dentro do meu cérebro, só alemão. (Andrade, 1963, p.314-15)

$\mathrm{O}$ autor de Amar, verbo intransitivo, romance centrado na figura de uma alemã, Fräulein Elza, relata aos seus leitores o esforço empreendido para abrir-se a um novo universo linguístico. Só assim, acredita ele, com doses de língua e cultura alemãs conseguiria equilibrar os efeitos da sólida formação francesa que o impedia de tornar-se genuinamente brasileiro. Em tom de confissão pessoal, Mário evoca o processo que o levou a optar pela cultura que o ajudara a derrubar seu "exagerado francesismo" num período (1822-1824) durante o qual o Brasil encontrava-se mergulhado num deserto literário desprovido de meios para firmar o nacional. Sendo os ingleses aliados dos franceses, Mário faz sua opção pelo que julgara ser o extremo oposto, a língua e a cultura alemãs que ele, de várias formas, ajudou a divulgar no Brasil. ${ }^{4}$

Mas eis que, ao lançar-se no novo aprendizado, instaura-se dentro dele um embate entre a cultura francesa que o habita e a cultura germânica que deseja adquirir. Seu campo psíquico se transforma, textualmente, num cinematográfico campo de guerra, espelhando aquele que se desencadeava no plano mundial. Os termos para descrever os embates não deixam dúvidas:

Com tanto germanismo, era natural, a guerra franco-prussiana se declarou irredutível em meu espírito. Mas aqui vem a razão por que [...] exclamei celebrando a sublimidade dos domínios da inteligência. É que se tratava de uma guerra $[. .$.$] de metáforas, de argumentos, de sensibilidades distintas. Às$ 
vezes os alemães avançavam sobre o exército Balzac, Dumas, Maupassant, Flaubert e a bala de maior calibre era o appelido "porco" dado uma vez a Balzac. $\mathrm{E}$ os franceses recuavam, entre elogios e discordâncias, às vezes reconfortados com uma boa oferta do "petit vin blanc" do Reno. Outras vezes eram os francos que, comandados por Baudelaire com Musset por ajudante de ordens, investiam contra o poderoso exército dos Hoelderlin, dos Heine, Novalis, Wieland, Lenau. Mas que franceses impossíveis! Faziam uma linha Maginot de caçoadas, que mais parecia um fogo de artifício aqui da Feira de Amostras. E era mesmo puro fogo de artifício. Os alemães resistiam galhardamente (eu queria que eles vencessem...) em seu lirismo mais puro, e aos poucos os francos recuavam outra vez, não sem uma certa tristeza minha, com muitos conselhos e consolos, cada qual com sua pipa de vinho do Reno, e até enjoadamente empanturrados de "delikatessen". (Andrade, 1963, p.315-16)

Publicando sua crônica no último dia do fatídico ano de 1939, quando a Inglaterra e a França declaram guerra à Alemanha, deflagrando o conflito que se tornará mundial, a escolha, por Mário, de um tema alusivo à inquietante conjuntura não foi aleatória, a começar pelo próprio título e sua adversativa: "Teutos, mas músicos" (grifo nosso) talvez tenha sido escrita com a intenção de recordar que, apesar do estigma da origem, o povo alemão talvez merecesse alguma benevolência por seu dom e contribuições dadas à música.

Encerra-se de modo harmonioso o conflito estrangeiro dentro de si, afinal tratara-se, de uma "guerra de flores" que cumprira seu papel, sem deixar atrás de si vencedores e vencidos. Além de curá-lo de sua intoxicação francesa, o conflito entre as duas culturas "estrangeiras" fez brotar dentro dele um saudável e vitorioso sentimento nacional:

Ninguém morreu nessa guerra, só alguns generais franceses saíram dela um bocado diminuídos de prestígio. E eu consegui me libertar da minha desumana galicidade. Não saí da guerra mais germanizado, isso nunca! Pelo contrário, pouco depois, fazia desconsiderações insolentes contra um Tieck, um Klopstock, e muitos outros encouraçados de pouca velocidade intelectual. Saí brasileiro, destemperadamente brasileiro e com enorme saúde mental. (ibidem, p.316)

Mário alerta, no entanto, contra certos "exageros". No Brasil não se podem repetir atitudes como a de países europeus que haviam proibido a execução de compositores alemães, o que seria inconcebível para qualquer "orquestra sinfônica do mundo, tanto mais de países americanos, [incapazes de] se sustentar culturalmente (e financeiramente) sem conservar como base de repertório Haydn, Mozart, Beethoven e o próprio Wagner" (ibidem, p.317). Por outro lado, evocando a presença de alemães - e de "israelitas", inclusive - nas principais sociedades musicais de São Paulo, do Rio e do sul do país, o que pede o musicólogo, preocupado com a valorização do nacional, é a inclusão, imaginada por Mário, de que ao menos "um terço de música brasileira" componha os pro- 
gramas daquelas entidades, pois, em geral, são formadas por "estrangeiros, indiferentes ao país e [que] dotados só de cultura tradicional, não compreendem, se irritam, não aplaudem as peças brasileiras do programa" (ibidem, p.318).

Fica uma vez mais evidenciado que se a formação literária de Mário se apoiou grandemente nas referências francesas, sua cultura musical muito deveu aos seus "professores alemães" com os quais manteve laços de "amizade". Com ambas as tradições, no entanto, ele instaurou um diálogo sem subalternidade. Em "Teutos, mas músicos", o musicólogo deplora os interesses "unilaterais", ou a "incompreensão granítica" de nossa música que, para além da valorização apenas nacional, pode ultrapassar esse limite para também alçar-se, como a música de Bach, Mozart ou Beethoven à condição de patrimônio humano (universal).

\section{“A modinha e Lalo" ${ }^{5}$ (6.2.1941)}

Em capítulo sobre as relações entre o autor de Macunaima e Roger Bastide, Fernanda Areas Peixoto (2000, p.84) afirma que "se Mário [...] não possui um número grande de textos sobre [o sociólogo francês], esteve atento à produção e à reflexão críticas $\mathrm{d}$ [este], dialogando com elas em diversos momentos de sua obra”. No campo musical, tal diálogo não se estabeleceu sem tensões, já que as análises ou explicações avançadas por Bastide contrariavam por vezes não só fatos observados por Mário como suas convicções (ibidem, p.84-7). Segundo Peixoto, uma das mais notáveis controvérsias travadas entre os dois estudiosos girou em torno do tema abordado na crônica ora estudada. Ao lado de dois outros artigos escritos por Mário de Andrade ("O desafio brasileiro" e "Desnivelamento da modinha”, ambos de 1941), "A modinha e Lalo" evidencia o núcleo das discordâncias dos dois homens acerca das modinhas imperiais, gênero anteriormente tratado pelo musicólogo paulistano no prefácio ao seu livro $\mathrm{Mo}$ dinhas imperiais (1930) e sobre o qual se debruçaria igualmente Roger Bastide num de seus artigos publicados em $O$ Estado de $S$. Paulo numa série intitulada "Estudos da sociologia estética brasileira" (Andrade, 1963, p.339). Baseando-se em conceitos estéticos de Charles Lalo, autor de L'art et la vie sociale (1921), Bastide discordaria das interpretações de Mário sobre as origens da modinha, acreditando que a apropriação das formas eruditas pelo povo - procedimentos chamado por Lalo de "desnivelamento estético" seriam "normais" (ibidem, p.86). Ao comentar o artigo de Bastide, publicado em 4 de outubro do ano anterior, Mário de Andrade discute a teoria que parecia invalidar suas afirmações. Ao contrário do que sustentava o sociólogo francês, servindo-se de Lalo, para Mário, com a modinha ocorrera no século XIX o fenômeno "raríssimo de uma forma erudita haver passado ao popular" (ibidem, p.339). Se tanto Mário quanto Lalo possuem em comum a ideia de que, muitas vezes, o artista erudito inspira-se no popular, em contrapartida para o filósofo francês a arte popular não é espontânea, mas sim uma junção de resíduos de uma arte aristocrática que caiu em desuso. E é exatamente neste quesito que Mário de Andrade discorda categoricamente das afirmações de Lalo. 
Para deixar claro seu ponto de vista, o crítico paulista elabora sua demonstração tomando por base as conviç̧ões herdadas do afinco com que há anos vinha se dedicando aos estudos musicais. Desse modo, enuncia-se como o especialista que é, fazendo uso de terminologia específica da área ("corte rítmico", "fórmula cadencial"), bem como de todo seu conhecimento a respeito do folclore brasileiro, o que lhe permite compreender amplamente as expressões da arte popular no Brasil. Seria essa uma maneira sutil de afirmar uma certa posição de superioridade em relação a Bastide, havia pouco chegado ao Brasil e já se transformando, como outros de seus conterrâneos, em explicadores do país? Para Mário de Andrade, o que mais fragiliza as afirmações de Lalo é a escassez de exemplos concretos que permitam a real compreensão de suas teorias - "exemplos nem sempre provados, mas pressupostos por ele" (ibidem, p.342) -, tal qual as generalizações perceptíveis em seus enunciados. Se seu discurso se pauta pela ponderação e prudência, nem por isso Mário deixaria de caracterizar o pensamento de Lalo como fruto de "confusionismo de terminologia e enganos consequentes" (ibidem, p.341).

Vê-se, pois, nessa crônica, a postura de Mário de Andrade crítico colocar-se firmemente em evidência e uma vez mais dialogando com seus "pares" europeus de igual para igual. Se suas asserções são questionadas, ele as rebate, como o faz com Lalo, valendo-se de exemplos fartos, perplexidades e provocações explicitadas em irônicos elementos paratextuais (sic, aspas):

[Segundo Lalo], "muitas (SIC) das nossas árias (SIC) mais populares derivam de antigos estribilhos de óperas favoritas do século XVIII", Lalo considera, só por isso, apenas por isso, apenas por essas muitas que estão longe de ser a totalidade $[\ldots]$ ser "todas" melodias eruditas que se popularizaram [...]. (ibidem, p. 342)

Em seu julgamento, o esteta francês àquela altura se afigura como incapaz de tecer conceitos sólidos e esclarecedores. Mário, porém, jamais se furtou a rever suas próprias posições. Alguns anos mais tarde, ao analisar a produção de cantadores nordestinos, ${ }^{6}$ Mário reavaliou seu parecer, reconhecendo que a tese de Lalo acerca do desnivelamento estético, sustentada anteriormente por Bastide, podia efetivamente aplicar-se a certos gêneros musicais brasileiros (Peixoto, 2000, p.89).

\section{"Romain Rolland, músico" (23.4.1944)}

Nesse texto, Mário de Andrade relembra os feitos de Romain Rolland (1866-1944), por ele venerado e tido como um modelo a ser seguido. A crônica dedicada ao recém-falecido teatrólogo, novelista e crítico de música francês, ganhador do Prêmio Nobel em 1915, encerra uma última homenagem e um desabafo. Inicialmente, Mário tenciona discorrer sobre os incontáveis escritos de Rolland sobre o universo musical e logo se dá conta de ter em mãos observações feitas pelo historiador da música francesa Henry Prunière, ponto de partida de suas ponderações. 
Na crônica, Mário fala a seus leitores de sua paixão pela obra de Rolland e lhes narra, no tom coloquial com que se aproxima de seus leitores, um fato curioso que the ocorrera depois de emprestar obras de Rolland a um amigo:

Amando os meus exemplares desadoradamente, uma vez fiz um sacrifício cujo heroísmo, só os bibliófilos sinceros podem apreçar: emprestei-os a um amigo moço que estava se dedicando à musicologia. Aliás franqueei toda a minha biblioteca a ele, o que fazia com que esse amigo às vezes tivesse dez e doze livros meus consigo. Eis que sucede um desastre e o rapaz morre. Lá estavam na casa dele as minhas primeira edições de Romain Rolland. Quando me apercebi disso, não soube resistir, fui lá. Mas a família se recusou a entregar nada, porque pretendia guardar a lembrança dos livros do filho, e não tinha certeza que os meus livros fossem meus. Aguentei isso na lata, amigos, vindo dum velho em preto e em lágrimas. Desde então principiei percebendo que o ex-libris não é granfinismo só, nem egoísmo não emprestar livros. Mandei fazer um ex-librisinho sem frase em latim, e escrevi em todas as minhas estantes: "Não empreste livro. A casa é sua, venha ler aqui". Continuei emprestando da mesma forma, está claro... (Andrade, 1963, p.373-4)

Mário confessa sua admiração pelo artista e indigna-se com a falta de reconhecimento de que Rolland era alvo em seu próprio país, onde era visto como um escritor menor, autor de obras que não refletem a alta literatura. Para o seu incondicional admirador brasileiro, Rolland "não só sabia dizer o que pensava profundamente, como sabia nos dar a compreensão intensa do que queria dizer. Que macacos me mordam si isso não é ser escritor" (ibidem, p.374). Segundo Mário de Andrade, o estilo do francês prendia-se justamente aos temas privilegiados por ele: "Romain Rolland nasce dos seus assuntos. Ele sabe que não existe estilo sem personalidade" (ibidem, p.375). A título de comparação, Mário enaltece os escritores franceses Mallarmé, Gide, Proust, além do irlandês James Joyce e do italiano Pirandello, que não pregam a "valorização do indivíduo, mas a revalidação do homem" (ibidem). O único brasileiro citado é o contemporâneo José Lins do Rego, alvo da crítica de Mário de Andrade na medida em que suas obras são, por vezes, "um estilo a procura de um assunto" (ibidem).

Contudo, para Mário de Andrade, a característica mais marcante de Rolland músico é sua atração por Beethoven, pela expressão máxima de humanidade - definida por Mário de Andrade como tentativa e erro - manifestada na obra do compositor alemão. Além disso, Mário elogia a capacidade compreensiva de Rolland diante de seus próprios ídolos, Beethoven e Goethe, verdadeiros "gênios".

Essa crônica de Mário, em sua simplicidade, se tece das impressões subjetivas de um grande admirador, mas mesmo assim nela encontram-se elementos comparativos que visam atestar a qualidade superior de Romain Rolland, presente em sua obra e em sua vida. 


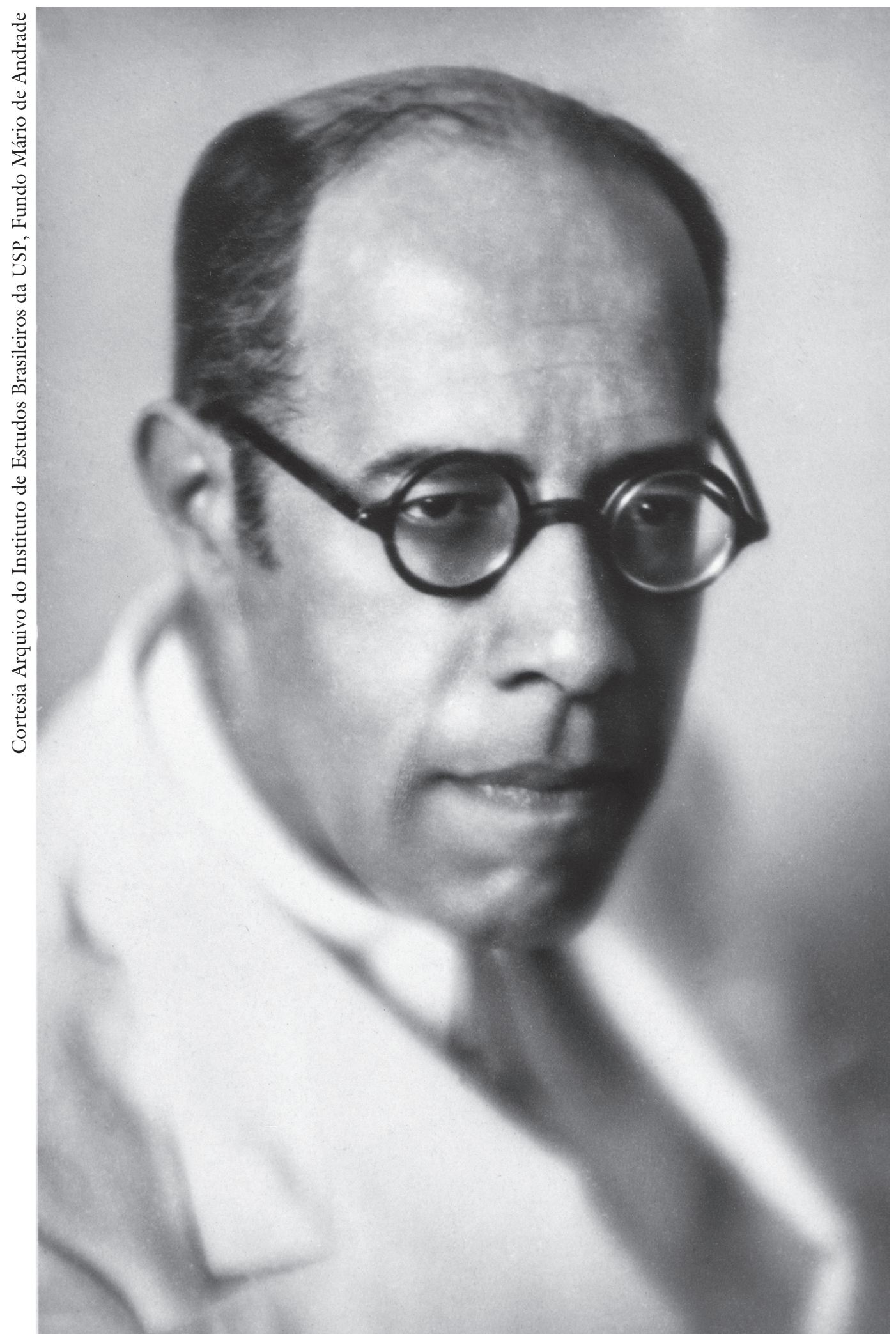

Mário de Andrade no Rio de Janeiro em 1937. 


\section{"Oferta musical" 7}

Entrelaçando poesia e música, Mário de Andrade tenta compreender o que seria a "musicalidade" de Paul Verlaine, termo esse que, de seu ponto de vista, não se refere à sonoridade verbal - presente também em Leconte de Lisle, Heredia, Mallarmé, Victor Hugo, La Fontaine e Racine -, mas a "certa flexuosidade delicada e elástica de fraseado, a uma especial doçura de dizer" (Andrade, 1963, p.382). Durante todo o percurso dessa crônica, o autor se interroga sobre esses traços temáticos e conduz o leitor de forma bastante pedagógica a tentar descobrir, junto com ele, o que faz de Verlaine um poeta tão musical.

Mário, sempre em dia com a leitura dos trabalhos de historiadores e críticos publicados em sua época, alude a dois teóricos franceses que apontaram a intrigante sonoridade dos versos de Verlaine ou um vínculo estreito desses com a música. O primeiro, citado no original, é o crítico literário Albert Thibaudet (1874-1936) que coloca a questão de uma forma que, seguramente, tocou a sensibilidade marioandradiana: "Si Baudelaire avait mis psychologiquement son coeur à nu, Verlaine l'a mis musicalement à nu. Aucune parole n'est plus que la sienne proche de ce qui ne peut être dit". ${ }^{8} \mathrm{O}$ segundo, Marcel Coulon (18731959), afirma que Verlaine possui uma "coleção de peças para canto". 9

Um paralelo, no entanto, poderia igualmente ser traçado entre os poemas de Verlaine com os dos alemães Goethe (1749-1832) e Heine (1797-1856) que serviram de inspiração para Schubert (1797-1828) e Schumann (1810-1856). O pensamento de Mário, porém, aprofunda-se verdadeiramente quando situa as comparações dentro do que, no fundo, constitui seu campo de predileção, a França. Com o crítico-professor, os leitores brasileiros aprendem que, desde Ronsard (1524-1585), a poesia francesa forneceu material para os compositores. No final do século XIX, o fascínio de alguns compositores pela poesia simbolista foi marcante. Mário comenta, pois, a importância de Verlaine, para, quiçá, o mais literário dos compositores franceses de seu tempo, Gabriel Fauré (18451926) que, antes de criar com La bonne chanson (1892), requintadas melodias para os versos esteticamente inovadores do "poeta maldito" Baudelaire, já havia transposto Gautier, Leconte de Lisle e Victor Hugo; Claude Debussy (18621918), segundo Mário, teria sido aquele que mais obras dedicou aos poemas de Verlaine ${ }^{10}$ por fim, Ernest Chausson (1855-1899) foi considerado o menos verlaineano dentre eles por ter musicado apenas dois poemas : La chanson bien douce e Le chevalier malheur. Quanto a Henri Duparc (1848-1933), Mário avalia severamente o compositor que, embora dono de uma melódica "flexuosa" e "sensual", "esqueceu Verlaine" ignorando as virtudes do texto do poeta para a conversão musical: "[Duparc] foi tão doente, coitado e deixou poucas melodias" (Andrade, 1963, p.383). É importante ressaltar a quantidade de autores e compositores franceses citados e comentados com minúcias nessa crônica, uma vez mais atestando os conhecimentos amplos e profundos de Mário sobre os mais variados campos da cultura francesa. 
Na crônica examinada, tenta-se, como de praxe, fazer comparações com o que se observa no Brasil. Mário afirma que os nossos simbolistas possuem uma poesia indiscutivelmente melódica. No entanto, poetas como Alphonsus e Eduardo Guimarães não foram musicados. Segundo Mário, de fato só foi possível perceber a criação de um vínculo real entre música e poesia após 1922, quando os compositores Villa-Lobos, Luciano Gallet, Lourenço Fernandez, Francisco Mignone e Camargo Guarnieri buscam inspiração nos poemas de Ronald de Carvalho, Bandeira, Drummond, Oneyda Alvarenga etc. ${ }^{11}$ Caso semelhante ocorre na França do século XVI, com Goudimel Manduit e Claude le Jeune inspirando-se em Baif e Ronsard. Na crônica, são citadas as seguintes canções compostas a partir dos poemas de Verlaine: "La chanson bien douce" e "Le chevalier malheur", de Chausson; "Chant d'automne" e "Bonne chanson", de Fauré ; "Ariettes oubliées" e "Fêtes galantes". Depois de citar canções baseadas em poemas de Bandeira, Mário afirma ser ele o mais musicado de todos os brasileiros, comparando-o, assim, a Verlaine. Fica, porém, visível que a "oferta musical" é incomparavelmente maior no campo francês cuja atualidade literária, musical e crítica é rigorosamente acompanhada por Mário e, graças a ele, por seus leitores.

\section{Considerações finais}

As crônicas musicais cujo tema se volta para a música, músicos e a crítica musical francesa aportam novas peças ao quadro ainda não completamente encerrado das marcas francesas e das impressões sobre a França na obra de Mário de Andrade.

No conjunto de textos analisados, depreende-se a escritura particular característica do intelectual modernista, dono de uma capacidade incomum de diluir assuntos complexos e delicados, conferindo-lhes um ar de conversas despretensiosas ou de animado, porém instrutivo, bate-papo com amigos. Mário de Andrade estabelece constantemente vínculos com seu leitor, como se esse fosse um de seus alunos ou simplesmente um colega com quem pode compartilhar e discutir suas ideias. Sem aconselhamentos explícitos (Moraes, 2007), o "professor" dá subsídios que podem auxiliar nas opiniões daqueles que o leem, inquietando-os, instilando-lhes surdamente o desejo de, por si mesmos, irem além.

No entanto, apesar da aparente descontração e do tom coloquial, o musicólogo não hesita em expor suas opiniões de maneira categórica, fundamentando-as sempre através de exemplos e demonstração da linha de raciocínio que o permitiu levantar tal argumento, chegar a esta ou àquela conclusão. Pode-se notar que se nos primeiros tempos a "fala" de Mário parece mais provocativa, vai aos poucos, com o peso de seus conhecimentos, tornando-se mais ponderado, ampliando e afinando seu método comparativo.

A oralidade e a demonstração pedagógica (o "professor" Mário talvez esteja imbuído da missão de "formar" seus leitores) impregnam as crônicas analisadas, assim como estão presentes nos demais textos reunidos em Música, doce 
música. O diálogo, a interação com os leitores é constante. Ora o crítico deseja convencê-los de seu ponto de vista, ora dirige-lhes perguntas retóricas, ora compartilha de sua erudição citando as obras e os autores estrangeiros, em sua maioria franceses, para um público culturalmente ávido, mas fisicamente distante do confronto direto com a cultura europeia.

As persistentes referências francesas formam uma espécie de cenário dentro do qual se desenvolverá o assunto central. Seguidamente, Mário dos faz entrever, como uma espécie de marca d'água, que a França está enraizada em sua formação artística e intelectual, às vezes funcionando de modo polêmico com seu desejo de valorizar a arte brasileira. Assim como, para analisar as obras e/ou as críticas musicais, ele lança invariavelmente mão de autores franceses, também com eles cria-se um diálogo, revelador de desequilíbrios, quando se abordam músicas, compositores e intérpretes brasileiros pouco ou nada conhecidos na pátria de Fauré e Debussy.

O nacionalismo acentuado e por muitos apontado como uma quase pulsão dentro da obra mariodeandradiana são imagens estereotipadas sobre o autor, imagens que podem soar como definitivas em uma leitura superficial. $\mathrm{O}$ interesse pelo nacional é um fato concreto, porém este traço brota da própria bagagem de cultura e leituras francesas que, consciente ou inconscientemente afloram nas palavras, opiniões e julgamentos críticos de Mário de Andrade: o que vemos são as persistentes, e às vezes infrutíferas tentativas de relativizar tal influência. ${ }^{12}$ A França marcava profundamente as experiências estéticas e musicais de Mário, mesmo tendo ele jamais se mostrado explicitamente partidário de determinada cultura estrangeira.

Por fim, analisando as críticas musicais, é perceptível que, mesmo nas tentativas de explicitar o nacional diante dos assuntos propostos, somente os exemplos estrangeiros, na sua grande maioria franceses, são realmente explorados e detalhados pelo crítico que não se furta a se colocar como "intérprete" da França para o público brasileiro. Tal fato evidencia que, mesmo ligado fortemente ao nacional, ainda assim, do alto de uma postura crítica e autocrítica, Mário de Andrade mantém suas referências e preferências assentadas nos moldes gauleses.

\section{Notas}

1 Ver "Cronologia" in Revista do Instituto de Estudos Brasileiros. São Paulo, n.36, p.247-56, 1994.

2 Nascido na Polônia, Chopin naturalizou-se francês.

3 Veja, a esse respeito, o seguinte quadro:

\begin{tabular}{|c|c|c|c|c|c|c|c|c|c|c|c|c|}
\hline \multicolumn{13}{|c|}{$\begin{array}{l}\text { Imigração alemã no Brasil por décadas de } \mathbf{1 8 2 4} \text { a } 1969 \\
\text { Fonte: Instituto Brasileiro de Geografia e Estatística (IBGE) }\end{array}$} \\
\hline Período & $1824-47$ & $1848-72$ & $1872-79$ & 1880-89 & $1890-99$ & 1900-09 & $1910-19$ & $1920-29$ & $1930-39$ & $1940-49$ & 1950-59 & $1960-69$ \\
\hline
\end{tabular}

4 Cf. Lopez (1996, p.63-64): “Temendo o francesismo, [Mário] aproximou-se dos 
alemães e descobriu uma cultura nova para ele, procurando entendê-la: literatura, artes plásticas, teatro, música, relações de amizade. Leu, estudou muito. Revelou aos brasileiros a arte e a literatura alemãs contemporâneas; acompanhou a produção dos alemães no Brasil. Essa divulgação, Mário a fez ao longo de seu trabalho de jornalista: crítica de arte, de livros, crônicas. Soube, por exemplo, mostrar o valor da dança expressionista de Chinita Ulmann e Carletto Thieben, pioneiros em nossa terra. Graças ao conhecimento do alemão, chegou ao lendário de Macunaíma em Vom Roroima zum Orinoco de Theodor Koch-Grünberg. Deixou inédita a Tradução Koch-Grünberg, em que toma texto sobre a música dos índios das Guianas, o mesmo estudo que tanto motivou o cubano Alejo Carpentier. Mário teve poemas seus traduzidos para o alemão por Inês Theltscher e Hilde Kowsmann, brasileiras. Chegando a guerra, repudiou com veemência e publicamente o nazismo; sua indignação estendeu-se até Amar, verbo intransitivo, onde, em 1944, acrescentou ao discurso do Narrador uma frase de acusação inflamada: 'Bárbaro, tedesco, infraterno germano infraterno'"

5 Charles Lalo, filósofo e "esteta francês", como o define Mário de Andrade, do século $\mathrm{XX}$, autor de L'Art et la vie sociale e Esthétique.

6 Mário de Andrade, “O canto do cantador”, in: Os cocos, 1984, p.384 apud Peixoto (2000, p.89).

$7 \mathrm{O}$ nome do jornal e a data de publicação deste artigo não foram encontrados, porém pode-se dizer que foi posterior a 1936, devido a dados fornecidos na leitura da crônica.

8 "Se Baudelaire pusera psicologicamente seu coração a nu, Verlaine o pôs musicalmente a nu. Nenhuma palavra, mais do que a sua, chegou perto do que não se pode ser dito" (tradução nossa). In: Histoire de la littérature française de 1789 à nos jours (1936).

9 A obra da qual esse excerto é retirado não é citada por Mário de Andrade.

10 Trata-se de Ariettes oubliées, Mandoline e Fêtes galantes.

11 Em sua crônica, Mário cita duas canções brasileiras inspiradas em textos poéticos. Trata-se dos poemas de Manuel Bandeira: "Azulão" (Jaime Ovalle; Guarnieri) e "Ondas da praia” (Guarnieri; Lourenço Fernandez). Informa também o musicólogo paulistano que Villa-Lobos criou um ciclo inspirado em "Epigramas", de Ronald de Carvalho, tendo a poeta Oneyda Alverenga inspirado o "mais belo ciclo de canções" de Francisco Mignone.

12 Em 16.4.1936, Mário de Andrade comentava no artigo "Decadência da influência francesa no Brasil" (Diário da Manhã, Recife): "Os brasileiros continuam a ler enormemente os livros franceses, a admirar e amar a França no que ela tem de admirável e amável. Apenas, pelo seu próprio engrandecimento, e pelas circunstâncias atuais do mundo, o brasileiro não pode mais se empobrecer num exclusivo amor..." (Andrade, 1993 b, p.5).

\section{Referências}

ALVES, H. Mário de Andrade. São Paulo: Escritor, 1973.

ANDRADE, M. de. Paris. Diário de Noticias. Rio de Janeiro, 31 mar. 1940. . Música, doce música. São Paulo: Livraria Martins, 1963. 
ANDRADE, M. Um crítico no jornal. In: Vida literária. Pesquisa, estabelecimento de texto, introdução e notas de Sonia Sachs. São Paulo: Hucitec; Edusp, 1993 a.

Vida literária. Pesquisa, estabelecimento de texto, introdução e notas de Sonia Sachs. São Paulo: Hucitec; Edusp, 1993b.

CASTAGNA, P. De volta ao jornalismo musical. In: Música e jornalismo. São Paulo: Edusp, 1993.

FAUSTO, B. História do Brasil. São Paulo: Editora da Universidade de São Paulo; Fundação do Desenvolvimento Educacional, 1994.

FERES, N. T. Leituras em francês de Mário de Andrade: seleção e comentários com fundamento na marginália. São Paulo: IEB, 1969.

FERNANDES, L. (Org.) Mário de Andrade escreve: cartas a Alceu, Meyer e outros. Rio de Janeiro: Editora do Autor, 1968.

LOPEZ, T. A. Uma difícil conjugação. In: Mariodeandradiando. São Paulo: Hucitec, 1996a.

A estreia poética de Mário de Andrade. In: Mariodeandradiando, São Paulo: Hucitec, 1996b.

MAINGUENEAU, D. Análise de textos de comunicação. Trad. Cecília P. de Souza e Décio Rocha. São Paulo: Cortez, 2001.

MORAES, M. A. de. Orgulho de jamais aconselhar: a epistolografia de Mário de Andrade. São Paulo: Edusp, 2007.

PAUlino, A. M. Os livros. O Estado de S. Paulo (Caderno de Cultura) 13 out. 1990. PEIXOTO, F. A. Diálogos brasileiros: uma análise da obra de Roger Bastide. São Paulo: Edusp; Fapesp, 2000.

PERRONE-MOYSÉS, L. Vira e mexe, nacionalismo. Paradoxos do nacionalismo literário. São Paulo: Cia. das Letras, 2007.

PINHEIRO, V. A França nos contos de Mário de Andrade. 2004, Dissertação (Mestrado) - Faculdade de Filosofia, Letras e Ciências Humanas, Universidade de São Paulo. São Paulo, 2004.

TONI, F. C. A música. O Estado de S. Paulo (Caderno de Cultura), 13 out. 1990.

RESUMO - Este trabalho apresenta a forte relação de Mário de Andrade com dois campos intrínsecos em sua produção: a musicologia e as referências à cultura francesa que desde cedo permearam sua trajetória intelectual. Analisamos aqui algumas crônicas reunidas em Música, doce música nas quais se evidenciam a visão e a postura singular do escritor brasileiro ante a música, músicos e críticos musicais franceses com os quais trava um diálogo de igual para igual.

PALAVRAS-ChaVE: Mário de Andrade, Musicologia, Música francesa, Música brasileira, Relações culturais Brasil-França.

ABSTRACT - This work presents Mário de Andrade's strong relationship with two fields intrinsic in his production: musicology and the French culture that permeated his intellectual trajectory from the very beginning. We analyze here some chronicles included in 
Música, doce música (Music, sweet music), which reveal the Brazilian writer's vision and particular position towards French music, musicians and musical critics with whom he establishes a dialogue on equal terms.

KEYWORDS: Mário de Andrade, Musicology, French music, Brazilian music, Brazil-France relations.

Ligia Fonseca Ferreira é professora do Departamento de Letras da Universidade Federal de São Paulo. @ - ligia.ff@uol.com.br

Ligia Kimori é doutoranda em Literatura Brasileira na Faculdade de Filosofia, Letras e Ciências Humanas da USP. @-lilofr@gmail.com

Recebido em 10.1.2013 e aceito em 4.2.2013.

I Departamento de Letras, Universidade Federal de São Paulo, Guarulhos, São Paulo, Brasil.

II Faculdade de Filosofia, Letras e Ciências Humanas, Universidade de São Paulo, São Paulo, São Paulo, Brasil. 